\section{Global health agency split over potential anti-terrorism duties}

Erika Check, Washington

A revision of the rules that govern the World Health Organization (WHO) is being held up as countries disagree on how the agency should deal with suspected bioterror events.

The United States and its allies are pressing the WHO to take the lead in bioterror investigations. But other nations - especially poorer ones where the body has a vital role in public health - say this would involve the agency in questions of national security, and would compromise its political neutrality.

"This is a very big issue," says Barbara Rosenberg, an analyst at the Center for Arms Control and Non-Proliferation in Washington. "Countries are already reluctant to report disease and permit WHO access because of repercussions on trade and tourism. Throwing the security aspect in there will only make it worse."

Last November, a working group was unable to agree on how the WHO should tackle bioterrorist threats, and a meeting in February also failed. A last-ditch attempt to resolve the issue is scheduled for 12 and 13 May - just days before the negotiators are due to present the revised guidelines to the World Health Assembly, the agency's governing body.

A working draft of the international health regulations says that if the intentional release of a biological agent in a member country is suspected, that country shall "provide to WHO all relevant public health information, materials and samples". This would force cooperation with the WHO; currently, the agency must be invited to enter a country before it conducts an investigation there.

Rosenberg argues that this change will be seen as a threat, and make countries less inclined to cooperate. Others add that the agency does not have enough funds to take on such a role without compromising its public-health mission. However, given the lack of alternatives, many analysts believe the WHO must take some part in bioterror inquiries, and they predict that the negotiations will agree on a softer version of the current draft.

"For public-health and political purposes, there needs to be a process for carrying out that kind of investigation," says Michael Powers, an analyst at the Chemical and Biological Arms Control Institute in Washington. "If we continue to put it off we're likely to have to carry out one without procedures in place."

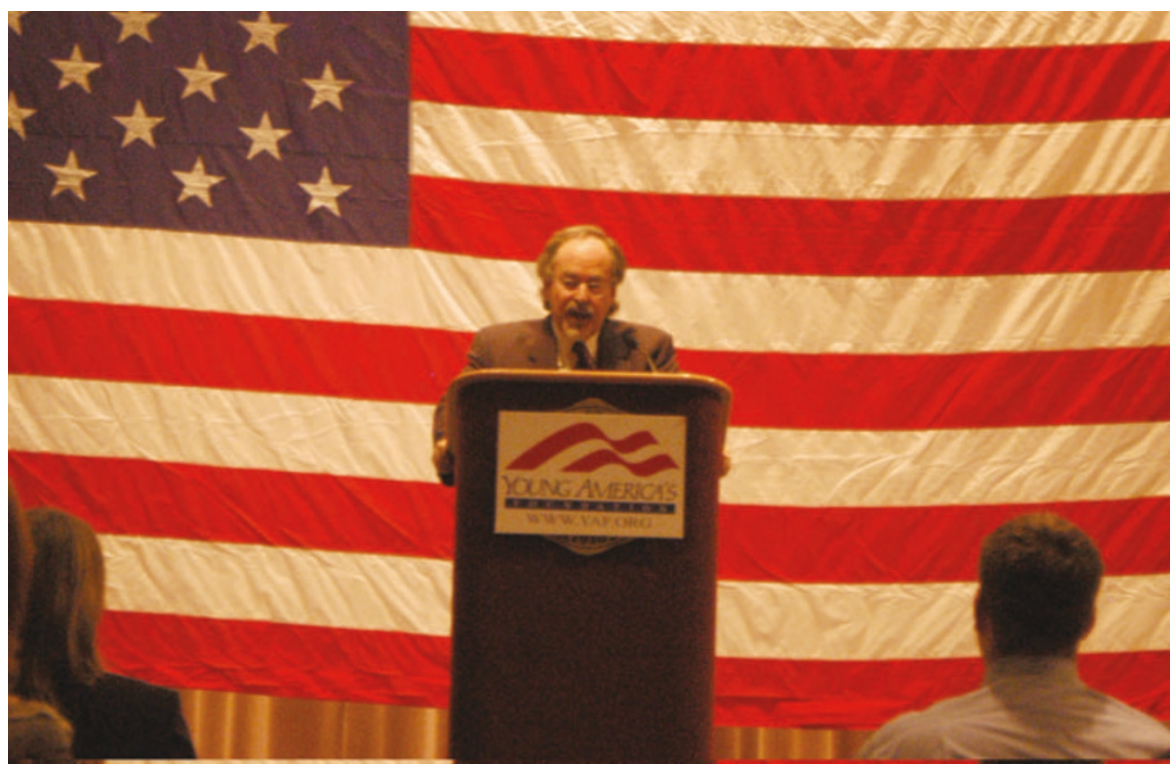

Flag waving: conservative David Horowitz is touring campuses to promote his academic bills of rights.

\title{
Professors bristle as states act to mould lecture content
}

Emma Marris, Washington

University faculty members in the United States are gearing up to oppose state bills that are being put forward by conservatives in the name of academic freedom.

Critics say that these 'Academic Bills of Rights', which are written to make sure that each side of an issue is presented in lectures at public universities, could in fact stifle academic freedom - and disrupt the teaching of science in contentious fields such as evolution and global warming.

"This would be a right-wing political takeover of the universities," says Tom Auxter, president of the United Faculty of Florida, the state's main academics' union.

Along with introducing protection from discrimination based on political or religious convictions, a bill being proposed in Florida calls on faculty members to refrain from introducing "controversial matter" unrelated to the course subject. It also requires them to present "serious scholarly viewpoints" other than their own.

Although the bill was written primarily with the humanities in mind, it would apply to all academic disciplines. On 22 March, Dennis Baxley (Republican, Ocala), who is backing the bill, said that it would make sure that alternatives to evolution are not shut out of universities.

"I do believe it has implications for the hard sciences," says Auxter. "It will waste a lot of time in the classroom because you will have to spend time covering a bunch of extraneous stuff - every crazy idea out there."

The American Association of University Professors (AAUP) is opposing similar bills nationally, saying that faculty members should decide course content. "This effort is part of a larger pressure on higher education to politicize the agenda," says Ruth Flower, the AAUP's director of public policy.

David Horowitz, a marxist radical turned conservative activist, has written a template for the bills introduced in Florida and elsewhere. The Center for the Study of Popular Culture, a Los Angeles-based think-tank cofounded by Horowitz, has helped to establish campus-based groups to back the measure.

The campaign has gathered steam in recent weeks, with bills introduced in several states. Georgia passed a non-binding motion supporting the idea in March 2004, and Colorado dropped the bill only when major universities agreed to adopt its language at the administrative level. Other states, among them Maryland and Washington, have already rejected bills or put them on hold.

The AAUP also objects to a clause in Horowitz's draft of the bill that requires universities and professional societies to "maintain a posture of organizational neutrality with respect to the substantive disagreements that divide researchers on questions within, or outside, their fields of inquiry". Most states have dropped this clause, as they do not have jurisdiction over national societies.

According to the AAUP, Florida could be the first state to pass the bill. Baxley, a close ally of Governor Jeb Bush, says the outraged reception is evidence that academics are too inflexible. "I've been called an ass in the school newspaper at the University of Florida," he says, "and that demonstrates exactly what I am talking about." 